Geopolítica(s) Revista de estudios sobre espacio y poder ISSN: 2172-3958

https://dx.doi.org/10.5209/geop.69349

\title{
Brazil in the Time of Coronavirus
}

\author{
Maite Conde ${ }^{1}$
}

Recibido: 8 de mayo de 2020 / Aceptado: 10 de mayo de 2020

\begin{abstract}
This essay outlines and analyses the spread of the coronavirus in Brazil. In doing so it explores how the pandemic, whilst initially brought into the country by the wealthy elite, has predominantly affected the country's poor, revealing structural inequalities that encompass class, race and ethnic differences, in which the poor are not afforded the right to live. It additionally examines the response to COVID-19 by the country's far right president, Jair Messias Bolsonaro, looking at how his laissez faire reaction to the virus builds on a history of violence against the marginalized, especially to the country's indigenous peoples, that has not just excluded them from the nation state but at times actively and violently eradicated them.
\end{abstract}

Keywords: COVID-19 pandemic; Brazil; Bolsonaro; structural violence; necropolitics.

\section{[es] Brasil en tiempos de coronavirus}

Resumen. Este ensayo describe y analiza la propagación del coronavirus en Brasil. Al hacerlo, explora cómo la pandemia, aunque inicialmente fue traída al país por la élite adinerada, ha afectado predominantemente a los pobres del país, revelando desigualdades estructurales que abarcan las diferencias de clase, raza y etnia, en las cuales los pobres no tienen el derecho a vivir. Además, examina la respuesta a la COVID-19 del presidente de extrema derecha del país, Jair Messias Bolsonaro, y analiza cómo su reacción de laissez faire al virus se basa en una historia de violencia contra los marginados, especialmente los pueblos indígenas del país, que no solo los ha excluido del Estado nación sino que a veces los ha erradicado activa y violentamente.

Palabras clave: pandemia de COVID-19; Brasil; Bolsonaro; violencia estructural; necropolítica.

\section{[pt] Brasil em tempos de coronavírus}

Resumo. Este ensaio descreve e analisa a disseminação do coronavírus no Brasil. Ao fazê-lo, explora como a pandemia, embora inicialmente trazida ao país pela elite rica, afetou predominantemente os pobres do país, revelando desigualdades estruturais que abrangem diferenças de classe, raça e étnica, nas quais os pobres não têm direito de viver. Além disso, examina a resposta à COVID-19 do presidente de extrema-direita do país, Jair Messias Bolsonaro, e analisa como sua reação de laissez-faire ao vírus se baseia em uma história de violência contra os marginalizados, especialmente os povos indígenas do país, que não apenas os excluiu do estado nação, mas que às vezes os erradicou ativa e violentamente.

1 Department of Spanish and Portuguese, University of Cambridge.

E-mail: mc534@cam.ac.uk 
Palavras-chave: pandemia da COVID-19; Brasil; Bolsonaro; violéncia estrutural; necropolítica.

Sumario. Introduction. 1. Class, Race and COVID-19: The Rich Contaminate Brazil. The Poor Suffer. 2. Coronavirus and Brazil's Indigenous Peoples: Building on a History of Exclusion and Extermination. References.

Cómo citar: Conde, M. (2020). Brazil in the Time of Coronavirus. Geopolitica(s). Revista de estudios sobre espacio y poder, 11(Especial), 239-249.

\section{Introduction}

"So what? I'm sorry. What do you want me to do about it?" These were the words of Jair Messias Bolsonaro, Brazil's president elect, when asked by reporters about the record of 474 deaths from coronavirus on Tuesday 28 April (Guardian newspaper). As Bolsonaro made his remarks, newspapers and television programmes were filled with stories about the mothers, fathers, sons and daughters losing their lives to the COVID-19 pandemic.

Bolsonaro's response sparked fury and was immediately condemned throughout the country. The next day the Estado de Minas newspaper printed the president's words on a black page beside the country's death toll that day: 5,017 (Figure 1). Social media became rife with criticism. Marcelo Freixo, leader of the left wing PSOL party, tweeted "Bolsonaro isn't just an awful politician and bad person, he's a despicable human being" (Guardian newspaper, 29 April 2020). Musician Nano Moura labelled Bolsonaro "a sociopath," and screenwriter Mariliz Pereira Jorge called his words "an insult" and "intolerable" (Guardian newspaper, 29 April 2020).

Bolsonaro's flippant reply is not surprising. Since Brazil confirmed its first case of the coronavirus on 26 February, the right-wing populist leader has constantly belittled the epidemic. He has labelled it nothing more than a "little flu;" has said that Brazilians can swim in excrement "and nothing happens;" he has rejected the media "hysteria" over its dangers; has purposefully undermined social distancing guidelines by mingling with his supporters and attending mass rallies protesting against lockdowns; and on 16 April he sacked his health minister, Luiz Henrique Mandetta, after he publicly challenged the president's behaviour.

But, in spite of Bolsonaro's denial, there is no escaping the scale of the tragedy in Brazil, which has become Latin America's deadliest hotspot for COVID-19 and it is projected to become the next global pandemic epicentre. At the time of writing, the country has reported more cases $(135,106)$ and more confirmed deaths $(9,146)$ than any of its South American neighbors, and researchers at Imperial College London estimate that Brazil's transmission rate will this week have been the highest in the world. The vertiginous rise in the numbers of confirmed cases has sparked an intense national debate about the extreme class, race and social inequalities in one of the most economically lopsided societies on earth; it has also shed light on the country's historical structural violence and how it is being revived today. 
Figure 1. Front-page of Estado de Minas newspaper (29 April 2020) $\rightarrow$
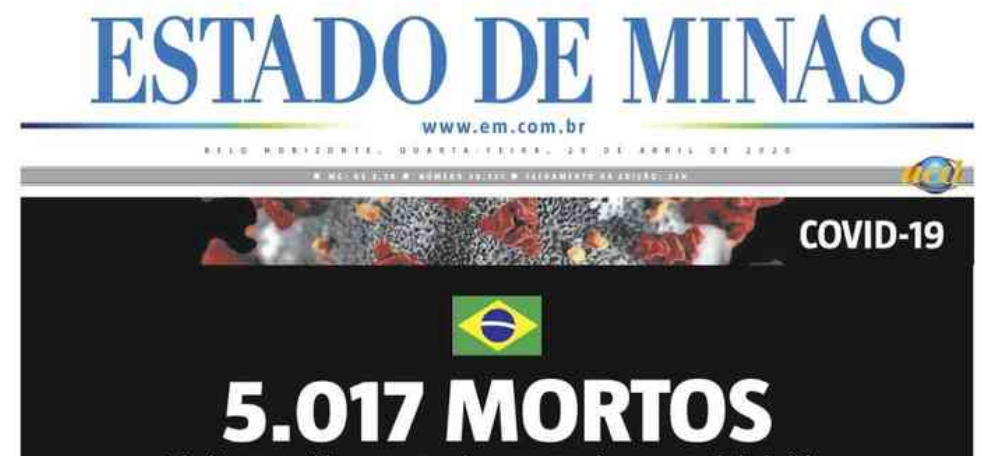

País ultrapassa a China, marco zero do novo coronavirus, no acumulado de óbitos

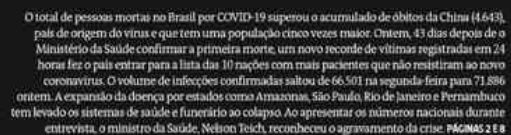

474

MORIES

REGISTRADAS

EM 24 HORAS
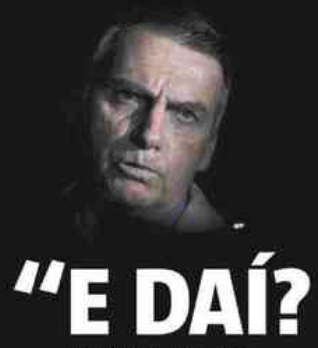

LAMENTO.

QUER QUE EU FAÇA O QUÊ?

EU SOU MESSIAS, MAS NÄO FAÇO MILAGRE."

Jair Bolsonaro, presidente do Brasil, no comentar o salto do número de mortes por COVID-19 no país

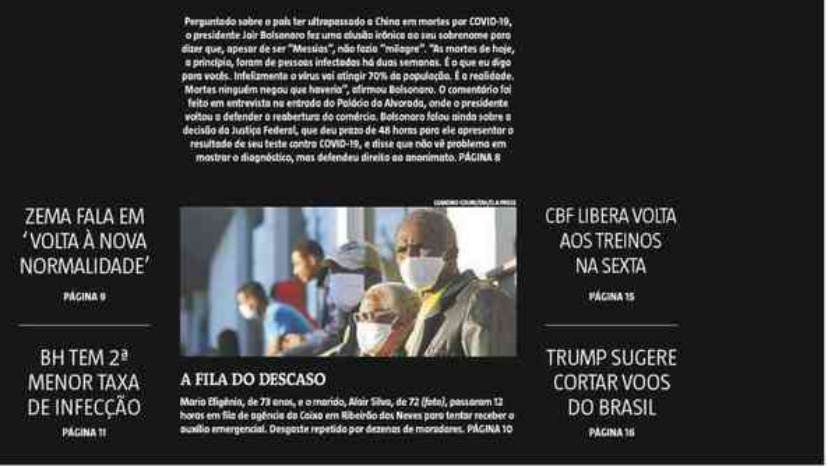

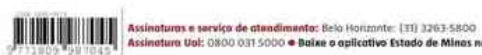

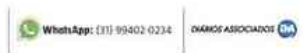

항

Source: Estado de Minas, 29 April 2020. Retrieved from https://www.em.com.br/app/noticia/capa-do$\mathrm{dia} / 2020 / 04 / 29 /$ noticia-capa-do-dia,1 142827/confira-a-capa-do-jornal-estado-de-minas-do-dia-29-04-2020.shtml 


\section{Class, Race and COVID-19: The Rich Contaminate Brazil. The Poor Suffer}

The first wave of cases in Brazil was primarily in the country's largely white elite, those who had travelled abroad where they exposed themselves to the virus and could then treat themselves in private hospitals. In March, for instance, descendants from Brazil's former royal family, the Braganças, gathered in a mansion in Ipanema to toast the engagement of 31-year-old Pedro Alberto de Orléans e Bragança the great-great-great grandson of Brazil's last emperor and his 26-year-old partner, Alessandra Fragoso Pires. Guests included Pires's mother and stepfather who had jetted in from their home in London and others from Belgium, Italy and the United States. More than half of the 70 people at the lunch subsequently tested positive for COVID-19, including the bride's father and grandfather, and the groom's aunt. Shortly afterwards, in April, at Rio de Janeiro's country club, which was founded in 1916 and has been frequented since by the elite of cariocan society, 60 of its 850 globe-trotting members had been struck down with COVID-19. That same month, Brazil's Health Ministry estimated that $60 \%$ of suspected cases of coronavirus were people who had travelled to Europe and the USA, where the pandemic was raging.

But, while COVID-19 was introduced by Brazil's jet set elite, it is now the poor and mostly black masses, that is the 14 million Brazilians who live in favelas and urban peripheries, who are suffering the most, without the luxury of being able to self-isolate at home or to resort to expensive private hospitals. One of the country's first recorded deaths was that of Cleonice Gonçalves, a 63-year old domestic worker. She fell ill suddenly while working at an apartment in the exclusive Rio neighbourhood of Leblon, where she was reportedly infected by her wealthy employer who had recently returned from holiday in Italy. Gonçalves' family called a taxi for her when they learned of her condition. It took the domestic labourer two hours of traveling through twisting roads to reach her home in the small town of Miguel Pereira. At 6pm she checked into the local hospital and by the following afternoon she was dead. According to four state and local officials, her boss had been feeling ill and had tested positive for coronavirus but did not inform Gonçalves, who had worked for the family for decades. For the black feminist intellectual Djamila Ribeiro writing in the Folha de São Paulo newspaper, this particular case exemplifies the precarious state of Brazil's poor. "It goes without saying" she notes, "that the most vulnerable will be the most affected. These are structural issues" (19 March, 2020).

Indeed, while the coronavirus was imported by the Brazilian elite vacationing in Europe it soon began to ravage the country's poor, ripping through favelas and urban peripheries where inhabitants suffer from a lack of running water, septic systems and health care facilities making the disease hard to control. On 27 March, for instance, Rio's elite neighbourhoods of Leblon, Copacabana and Barra da Tijuca reported 190 confirmed cases of COVID-19. In contrast, the city's lowincome areas of Campo Grande, Bangu and Irajá reported only eight cases. All of this changed rapidly. Just a week later those poorer neighborhoods reported 66 cases and today the numbers are in the hundreds, although experts state that the real rate of cases in poorer areas is undoubtedly far higher than reported due to a lack of testing. Rio's secretary of health Edmar Santos - who was himself diagnosed with COVID-19 in early April - admitted that underreporting and testing 
amongst the poor means that official figures do not capture the scale of the crisis. ${ }^{2}$ Poor Brazilians are also more likely to die if infected, due to higher levels of preexisting conditions and less access to healthcare. Epidemiologist Keny Colares noted that most low-income patients were showing up at hospitals days after they should have sought medical attention, leading to greater fatalities. In Rio's exclusive neighborhood Leblon, for example, just $2.4 \%$ of confirmed cases have resulted in deaths - roughly in line with global trends and suggesting a relatively accurate picture of infection numbers. In Irajá, meanwhile, the death rate is $16 \%$, while in São Paulo's favela Brasilandia, it is a staggering 52\%.

While state governors and health officials, like Santos, have implemented social distancing and lockdown measures, few of those living in poor neighborhoods are adhering to quarantine measures, with life continuing more or less as usual. Shops and bars are bustling and the poor, who tend to work in the informal economy, are continuing to go to work. All of this has been intensified by the confusing messages regarding the virus. Bolsonaro's anti-scientific stance has made many people ignore state measures. Indeed, despite the rising death toll Bolsonaro has pushed to restart the economy, describing shelter-in-place policies as a poison that could kill more via unemployment and hunger than the virus.

This situation has led gangs and drug traffickers to enforce their own curfews in favelas, amid growing fears of the impact the virus will have on its poor citizens. Gang members in the Cidade de deus favela in western Rio, for example, have ordered residents to remain indoors after $8 \mathrm{pm}$. A video recorded in the favela and circulated on social media includes a loudspeaker broadcasting the alert that "anyone found walking around outside will be punished." A report in the Rio newspaper Extra stated that gang members with loudhailers were moving around the Cidade de deus telling its 40,000 residents "we are imposing a curfew because nobody is taking coronavirus seriously. It's best to stay at home" (Extra newspaper, 24 March, 2020).

Cidade de deus' gangsters are not the only outlaws attacking the coronavirus in Rio's densely populated favelas, which are home to about two of the city's seven million residents. In Rio's Morro dos Prazeres, gang members have told residents only to circulate in groups of two, while in Rocinha, one of Latin America's biggest favelas, traffickers have also decreed a curfew after $8.30 \mathrm{pm}$ promising reprisals for those who do not conform. In Santa Marta, a favela that sits in the shadow of Rio's Christ the Redeemer statue, traffickers have been handing out soap and have placed signs near a public water fountain at the community's entrance asking people to "Please wash your hands before entering the favela." Meanwhile, in some sections of the Complexo da Maré, a sprawling favela near Rio's international airport, traffickers have told shops and churches to reduce their operating hours.

Other favelas in which curfews have been imposed include Pavão-Pavãozinho in Copacabana, Cantagalo in Ipanema, and Vidigal. Inhabitants of these neighborhoods are staying indoors for fear of the coronavirus and also of the gangs' orders and threats. One Cidade de deus resident noted, however, "the traffickers are doing

2 He believes that Rio, with a population of 17 million, has more than 15 times the official figure. A study published in Globo newspaper suggested the national figures were being similarly underestimated, with more than $1.2 \mathrm{~m}$ likely infections, compared with the official figure of under 74,000 . That would mean Brazil had more cases than the United States, so far the country worst hit by the pandemic, which has about 1 million. 
this because the government is absent. The authorities are blind to us." All of this highlights what Alba Zaluar and Marcos Alvito (1998) refer to as the 'dualism' or 'duality' in Brazil's cities, that is, a polarization between the formal and informal urban space caused by the absence of the state in peripheral areas. For Zuenir Ventura (1998), this polarity has created 'divided' or 'broken' cities, which results from varied and complex forms of state policy failure and results in a form of social and racial apartheid and exclusion. Indeed, Edmund Ruge, a Rio-based editor for the RioOnWatch news site which covers the favelas, has said the imposition of curfews by gangs speaks to the Brazilian state's longstanding neglect of such areas.

Faced with this neglect, favela activists have been scrambling to respond to the coronavirus crisis with food donations and awareness campaigns, and projects such as \#COVID19NasFavelas. In Cidade de Deus, the Frente CDD has also been working to raise awareness in the community, as have communicators in Rio's Complexo Alemão favela, by creating banners, speaking face-to-face with people and handing out leaflets emphasizing the need to stop the spread of coronavirus. Favelas in other cities around the country have seen similar initiatives. In São Paulo, the website Peripheria em movimento created a podcast Pandemia sem neurose to provide information. In Heliópolis, São Paulo's largest favela, the Union of Residents and Associations has been holding collections for food and hygiene items. They also conducted an online survey on the impacts of coronavirus on the favela between 27 and 29 March. The 653 responses clearly illustrate the economic implications: 68 per cent of families living in Heliópolis have lost some of their monthly income since the virus restrictions were put in place. Of these, 19 per cent have lost their entire income. The union directly deals with local concerns, something that is also evident in the Laboratorio de jovens comunicadores (Laboratory of Young Communicators) in the periphery of the city of Belém. This group was hastily formed in March to monitor official communication and amplify the concerns of the neighborhood in the context of the pandemic, producing information designed for local realities. Teacher Lilia Melo who coordinates the project, emphasizes the importance of the local communicators at this time. "We're taking advantage of our network to offer guidance on prevention and combat of the virus for young people in a language they understand. We realised that there are some young people in the neighbourhood who still haven't realised how serious this is. Because of their reality, the difficulties they face, they tend to mock the recommendations from the state and federal governments, which don't speak to the reality of the periphery" (Latin American Bureau, 10 May 2020) she says. This question of language also arose for filmmaker Yane Mendes, who decided to adapt the official Ministry of Health information for the 2,500 residents of the Totó favela, in Recife, the capital of the state of Pernambuco. Concerned by the city government's failure to provide informative material on the prevention of coronavirus, she went looking for posters. Dissatisfied with the dry official communication, Yane made her own posters and put them up next to the official ones - effectively translating them.

Other local groups have made efforts to directly engage with state authorities. On March 23, The Rocinha Residents Association sent a letter signed by representatives of different favelas to Rio's governor Wilson Witzel, outlining seventeen proposals to combat the pandemic. These included providing food baskets to favela residents, especially the elderly; distributing basic hygiene kits, including hand sanitizer and protective equipment, to families living in favelas; the resumption of 
Community Health Agents in favelas; the immediate suspension of all evictions, judicial or extrajudicial, in favelas; exemption from electricity payments and guaranteed attention for severe cases amongst favela residents by increasing the number of beds in private and public hospitals and renting empty hotels. As of today, these proposals have yet to be implemented.

If the spread of COVID-19 has exposed the vulnerability of Brazil's urban poor, it has also highlighted the extent to which the death of a part of the country's population can be included in calculations and political managements, what Achille Mbembe (2019) calls necropolitics, which entails the right to expose people (including a country's own citizens) to death. This necropolitical approach is clearly at the heart of Bolsonaro's laissez faire attitude to COVID-19, evident on 21 March when, referring to the certainty of a rise in coronavirus-related deaths especially amongst the poor, he noted "Will some die? Yes, some people will die. I am sorry. This is life. We do not close car factories due to the fact that there are traffic accidents" (Wired, 7 May 2020).

Necropolitics has of course always been part of the DNA of Brazilian society and its divided cities. In 2017, more than 150,000 Brazilians died from poor medical health and 50,000 from lack of access to health care. 35 million lack access to running water. And in favelas, inhabitants are routinely killed because of police interventions. In 2019, for instance, 1,810 residents in Rio alone died as a result of police crackdowns. Brazil has always had an unequal distribution of the opportunity to live and die. Bolsonaro's words, therefore, and his attitude to the coronavirus, much like that of the country's elite who imported and transmitted it, are part of decades of social segregation and attacks on the country's precarious populations, especially its black population. Brazil's COVID-19 crisis, is in this sense, a crisis of sovereignty, revealing the absence of the state, which fails to provide health, that is to sustain the life, of all of its citizens.

\section{Coronavirus and Brazil's Indigenous Peoples: Building on a History of Ex- clusion and Extermination}

It is not just Brazil's urban poor who are disproportionately threatened and suffering from COVID-19. Indigenous communities in the Amazon region are also in danger of being 'wiped out' by the coronavirus, according to health experts. Respiratory illnesses, like those that develop from the influenza virus, are already the main cause of death for native communities and COVID-19 is now encroaching on the indigenous. By April the coronavirus had reached indigenous territories in the Amazon basin that are the size of France and Spain combined and April 13 saw the first victim of COVID-19, a 15-year-old boy, member of the Yanomami community. Since then a further three further members of the Yanomami have died.

For Dr Sofia Mendoça, a researcher at the Federal University of São Paulo (Unifesp) "there is an incredible risk of spreading the virus across the native communities and exterminating them" (qtd. in BBC Brazil News, 6 April 2020). She believes that coronavirus would have a similar impact to previous outbreaks of highly contagious diseases like measles. In the 1960s, a measles epidemic among the Yanomami community killed nearly $9 \%$ of those infected. As with the urban periphery, many indigenous communities lack the means to reduce the contagion, 
like hand sanitizer and water and soap. People too live in close proximity with each other, sharing utensils which will help the disease spread quickly. Indigenous peoples also live in areas where there is limited access to health care.

There is little expectation or hope that the state will intervene and help the indigenous communities fight against coronavirus. Over the years Bolsonaro has made numerous racist remarks about indigenous people. On April 12, 1998, he declared that it was "a shame that the Brazilian cavalry has not been as efficient as the Americans who exterminated the Indians" (qtd. in Correio Brasiliense Newspaper, April 12 1998). On February 8, 2018 he stated that if he became president "there will not be a centimetre more of indigenous land" (qtd. in Dourados Matto Grosso do Sul Newspaper) later correcting himself to say that he meant not one millimetre (qtd. in Globo Newspaper, August 3, 2018); on January 23, 2020 he said "the Indians are evolving, more and more they are human beings like us" (qtd. in OUL Noticias); and on 24 January 2018 he declared at a speech that indigenous peoples, as well as Afro-Brazilians are "not fit for anything, not even procreating." Bolsonaro's words clearly signal overt discrimination; they also point to a history of exclusion and difference to indigenous communities in Brazil, which have long been considered outsiders to the nation.

From the start of the First Republic (1889-1930), Brazil's indigenous peoples were viewed as pariahs and non-citizens of the nation state. The spiritual conquest of the New World followed the logic of cleansing and persecution against indigenes on religious grounds. Modern nationalism built on this, culturally and economically, and in Brazil, the subjugation of Indians was reformulated according to the needs of the modern nation of order and progress, which either sought to exterminate communities or 'assimilate' them as workers. In the early $1900 \mathrm{~s}$, anthropologist Hermann von Ihering argued that Indians were incapable of learning and that they were "indolent and indifferent and would not make a minimum contribution to our culture and progress" (Andermann, 2007, p.69). In his 1905 article "Anthropology in the State of São Paulo," Ihering even went as far as recommending the extermination of the state's Amerindian population, writing "The Indians of the state of São Paulo do not represent an element of labor and progress. As in other states of Brazil, no serious and continuous work can be expected from civilized Indians, and they are an obstacle for colonizing the backland regions they presently occupy, it seems there is no other means at hand than to eliminate them" (ibidem.). The scientist ended another article by noting that "it is worth registering here what the American general Custer said: the only good Indian is a dead Indian" (Diacon, 2004, p.124). Ihering's racism echoed discussions about the racial inferiority of the indigenes put forward by other intellectuals at the time. In 1911, physician and pioneering eugenicist Afranio Peixoto wrote of the inevitable disappearance of the "subhuman races" of indigenes; and historian Silvio Romero critiqued indigenous populations, who he regarded as "the lowest race on the ethnographic scale" (ibid., p.123). Viewing indigenous peoples as sub-races, Romero insisted on a break with Indianism and its object as a precondition for Brazil's progress. He criticized the indo-mania that had turned Brazil into a self-indulgent, backward nation, idealizing an indigenous population that was among the least developed in the world (Andermann, 2007, p.94).

Bolsonaro's recent statements eerily echo these historical proclamations and critiques which have placed the indigenes as "alien to modernity," to cite Jean Franco 
(2013, p.45). His words are clearly the result of decades, even centuries, of a discourse of discrimination. Although we should not conflate the effects of ethnic and gender identity, Judith Butler's assertion (1990) in reference to gender that the epistemological mode of appropriation, instrumentality and distantiation, belong to a strategy of domination that pits the I against the Other, which is in turn sedimented through a discourse of repetition can be applied to ethnic difference in Brazil. The consequences of indigenous difference, its supposed otherness to the modern, was often carried to violent fruition. In the late 1800 s and early 1900s, rubber tappers and local agricultural caudilhos in the Amazon basin frequently attacked the natives in an effort to expropriate their lands or their labor. In the early $1820 \mathrm{~s}$, for instance, a six-year battle against the western Bororo on the eastern side of the Paraguay river, led by influential landowner and military officer João Carlos Pereira Leite, left 450 Bororo dead and 50 imprisoned. These prisoners, later deemed to be 'pacified,' were assimilated as forced labor on Leite's farm. In the late nineteenth century, the provincial government of Mato Grosso founded two military settlements near the São Lourenço river in order to integrate the Bororo communities. Lacking an effective integration system, the settlements degenerated: drunkenness, sex and fighting led to fierce clashes between Indians and soldiers. Far from alien, the indigenous peoples in Brazil have had a long history of contact with 'outsiders,' which has been violent and assimilationist.

This history is prescient today and not just discursively. Since taking office Bolsonaro has avowed open season on the Amazon rainforest, pledging to take land away from indigenous communities. On February 5, 2020 the president presented a bill to Congress to regulate mining, hydroelectric power projects and other commercial enterprises in Indigenous territories. The bill effectively invites encroachment on and deforestation of Indigenous lands, giving carte blanche to cattle ranches and rogue loggers. ${ }^{3}$ The result is that indigenous people have been threatened, attacked and, according to community leaders, murdered by people engaged in deforestation.

The bill comes as no surprise, given Bolsonaro's dismissiveness of indigenous peoples and their rights. Today these attitudes are being revamped in the context of the coronavirus, with the pandemic being used to usher in laws that will lead to increased occupation of indigenous lands and deforestation in the Amazon, amid warning by campaigners that further environmental disruption could lead to new pandemics in the area. Indeed, while the crisis has seen most industries grind to a halt, government data suggests that deforestation in Brazil's Amazon rose $30 \%$ in March compared to the period last year, with the most recent data suggesting the trend has continued in April. There has also been an increase in forays into indigenous lands by miners and land-grabbers as civil and official protection efforts are scaled back for fear of infection. With the cuts to protection there is nothing to protect the indigenous from pandemics brought in from outsiders.

\footnotetext{
3 Deforestation in Indigenous land in the Amazon increased 65 percent from August 2018 to July 2019, according to INPE. The Indigenist Missionary Council (CIMI), a nonprofit organization, reported that from January through September 2019 there were 160 incursions into Brazil's indigenous land by people engaged in illegal mining, logging, and land grabs.
} 
In a recent open letter to Brazil's president, photographer Sebastião Salgado and a global coalition of artists and celebrities warned that the pandemic meant that indigenous communities in the Amazon faced an extreme threat to their survival. "Five centuries ago, these ethnic groups were decimated by diseases brought by European colonizers (...). Now, with this new scourge spreading rapidly across Brazil [they] may disappear completely since they have no means of combatting COVID-19," they wrote. ${ }^{4}$ Indigenous peoples are attempting to combat the spread of coronavirus. Some communities have split into smaller groups and are seeking refuge inside the forest, repeating mechanisms they used to avoid extinctions during past epidemics. The virus though has already made incursions into the area and Manaus, the capital of Amazonas and the state where part of the Yanomami reserve is located, is by far the worst city in Brazil so far hit by COVID-19.

The coronavirus appears to have reached the isolated, riverside metropolis of more than 2 million people on March 11, imported by a 49-year-old woman who had flown in from London. Six weeks later it had taken a terrible toll, with more than 100 people dying each day. This month the city expects to bury 4,500 people. With so many fatalities authorities are performing night-time burials and funeral homes have run out of coffins. In Parque Tarumã, Manaus' biggest cemetery, excavators carved out mass graves called trincheiras (trenches) in which the dead were stacked in three-mile piles. ${ }^{5}$

Emergency and health services in Manaus are also buckling under the strain with ambulances roaming the city for hours in search of hospitals to admit the ill they have collected. Videos have emerged of hospitals showing corridors lined with corpses shrouded in body bags and in one an unconscious patient is seen with his head wrapped inside a ventilator hood improvised from a large plastic bag. There is a shortage of mechanical ventilators, of oxygen, staff and stretchers.

There are a number of reasons for the intensity of the catastrophe in Manaus. The virus struck at the end of the rainy season when respiratory illnesses are rife and hospitals already stretched. The city's underfunded health system was also poorly equipped and doctors and other medical workers began contracting the disease themselves. Many also believe that corruption and the government's failure to implement containment measures is also to blame. It took 10 days after the first case was confirmed, on 23 March, for the state governor, Wilson Lima, to declare a state of emergency, ordering non-essential businesses to close. Yet even with the rising numbers of fatalities, social distancing is being ignored with people refusing to remain at home. The city's mayor, Arthur Virgilio, has pleaded for people to take the virus seriously but has blamed Bolsonaro. "It saddens me to know these lives could have been saved and weren't saved, in part because Brazil's leader said it was OK to go out" (qtd. in Guardian newspaper, 30 April, 2020). Virgilio has accused Bolsonaro of offering Brazil's citizens a false and dangerous choice between "freedom" and the "prison of social isolation." "He is offering freedom but it

\footnotetext{
4 The open letter was vublished sirtually, https://secure.avaaz.org/po/community_petitions/presidente_do_brasil_e_aos_lideres_do_legislativo_ajude_ a_proteger_os_povos_indigenas_da_amazonia_do_covid19/?cZZUvqb\&utm_source=sharetools\&utm_mediu $\mathrm{m}=$ copy\&utm_campaign=petition-994813ajude_a_proteger_os_povos_indigenas_da_amazonia_do_covid $19 \& u$ tm_term $=Z Z Z U v q b \% 2 B p o$ This occurred until a revolt from mourning families saw the practice halted.
} 
is a false freedom that could represent a kind of genocide," he said (Qtd. in Guardian Newspaper, 30 April, 2020).

$* * * *$

Rio-based writer, Pedro Doria, believes the coronavirus' spread throughout the country's marginalised could carry a heavy political price for president Bolsonaro, whose call for a relaxing of containment measures is an attempt to ingratiate himself with the poor. "What is hurting people in the favelas is the economy. So, right now Bolsonaro is making lots of sense to them," Doria said. But he believes that attitudes will change "the moment people we know start dying. (...). People will not forget that he said it was OK to go out on the streets" (qtd. in Guardian newspaper, 25 April, 2020). Public backlash, at least amongst the middle classes, has indeed intensified, with nightly panelaço protests across Brazil's major cities, where dissenters express their dissatisfaction with Bolsonaro by pummelling saucepans from windows and balconies. In spite of these protests Bolsonaro has not altered his message. While state mayors and governors have declared quarantines and lockdowns in major cities, the president has decried these arguing that life must go on as normal. On Sunday 3 May, he stirred up street protests in Brazilian cities against lockdown measures in defiance of his own health ministry's appeals for citizens to stay at home. This when the numbers of deaths had risen to well over 7,000 .

\section{References}

Andermann, J. (2007). The Optic of the State: Visuality and Power in Argentina and Brazil. Pittsburgh: University of Pittsburgh Press.

Butler, J. (1990). Gender Trouble. Feminism and the Subversion of Identity. New York: Routledge.

Diacon, T. A. (2004). Stringing Together a Nation: Cândido Mariano da Silva Rondon and the Construction of a Modern Brazil, 1906-1930. Durham, NC: Duke University Press.

Franco, J. (2013). Cruel Modernity. Durham, NC: Duke University Press.

Mbembe, A. (2019). Necropolitics. Durham, NC: Duke University Press.

Ventura, Z. (1994). Cidade partida. Rio de Janeiro: Companhia das letras.

Zaluar, A., \& Alvito, M. (1998). Um século de favela. Rio de Janeiro: FGV Editora. 